\title{
Quantitative Structure-Activity Relationship (QSAR) Study of Resveratrol-Oxadiazole Hybrids with Antiproliferative Activity in Breast Cancer Cells
}

\author{
Santos, A. A.; Brito, V. B. M.; Castro Silva, J. W.; Alencar-Filho, E. B.* \\ Rev. Virtual Quim., 2019, 11 (2), 475-487. Data de publicação na Web: 29 de março de 2019 \\ http://rvq.sbq.org.br
}

\section{Estudo da Relação Quantitativa Estrutura-Atividade (QSAR) de Híbridos Resveratrol-Oxadiazóis com Atividade Antiproliferativa em Células do Câncer de Mama}

Resumo: Produtos naturais são uma fonte inesgotável de novos compostos bioativos. Polifenóis contendo a porção estilbeno estão presentes em várias espécies vegetais, possuindo um conhecido potencial quimioterapêutico com baixa toxicidade. Dentre estes, destaca-se o resveratrol, um composto abundante na uva e no vinho tinto que tem apresentado atividades promissoras contra vários tipos de linhagens de células tumorais, sendo assim um bom ponto de partida para o desenho de novos fármacos. Nas estratégias modernas de desenho de drogas, o estabelecimento de relações quantitativas entre a estrutura química e a atividade biológica é parte crucial. Neste estudo, apresentamos um estudo QSAR inicial baseado em híbridos resveratrol-oxadiazóis previamente sintetizados, com atividade contra células do câncer de mama, identificando descritores moleculares que podem ser úteis para proposições qualitativas e avaliações quantitativas de análogos mais ativos.

Palavras-chave: Híbridos resveratrol-oxadiazóis; câncer de mama; QSAR; OPS; descritores dragon

\begin{abstract}
Natural products are an inexhaustible source of new bioactive compounds. Polyphenols containing stilbene moiety are present in various plant species and have a known chemotherapeutic potential with low toxicity. Among them, the resveratrol is a compound abundant in grape and red wine that has presented activities against some types of tumor cell lines, being a good start point to the design of new drugs. In the modern drug design process, the establishment of quantitative relationships between chemical structures and biological activities is a crucial part. In this study, we present an initial QSAR modeling based on previously synthetized resveratrol-oxadiazole hybrids, with antiproliferative activity in breast cancer cells, identifying molecular descriptors that can be useful in the qualitative proposition and quantitative evaluation of more active analogs.
\end{abstract}

Keywords: Resveratrol-oxadiazole hybrids; breast cancer; QSAR; OPS; dragon descriptors.

\footnotetext{
* Universidade Federal do Vale do São Francisco, Laboratório de Modelagem Molecular Aplicada à Farmácia (LAMMAF), Colegiado de Farmácia, CEP 56304-205, Petrolina-PE, Brasil.

Medilson.beserra@univasf.edu.br DOI: $10.21577 / 1984-6835.20190036$
} 


\title{
Quantitative Structure-Activity Relationship (QSAR) Study of Resveratrol-Oxadiazole Hybrids with Antiproliferative Activity in Breast Cancer Cells
}

\author{
Aline A. dos Santos, ${ }^{a}$ Vinicius B. M. de Brito, ${ }^{a, b}$ Joseph W. Castro Silva, ${ }^{a}$ \\ Edilson B. de Alencar-Filho ${ }^{a, b, c, *}$ \\ a Universidade Federal do Vale do São Francisco, Laboratório de Modelagem Molecular \\ Aplicada à Farmácia (LAMMAF), Colegiado de Farmácia, CEP 56304-205, Petrolina-PE, Brasil.

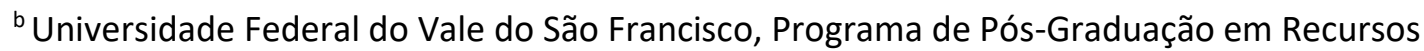 \\ Naturais do Semiárido, CEP 56304-205, Petrolina-PE, Brasil. \\ ' Universidade Federal do Vale do São Francisco, Programa de Pós-Graduação em Ciências da \\ Saúde e Biológicas, CEP 56304-205, Petrolina-PE, Brasil \\ * edilson.beserra@univasf.edu.br
}

Recebido em 6 de março de 2019. Aceito para publicação em 6 de março de 2019

\section{Introduction}

2. Material and Methods

2.1. Molecular structures and geometry optimizations

\section{Results and Discussion}

\section{Conclusion}

\section{Introduction}

The "Cancer" word is associate to a group of more than 100 manifestations, characterized by the disordered growth of cells in tissues and organs, which can spread to other regions in a phenomenon known as metastasis. ${ }^{1}$ These cells multiply rapidly, characterizing the formation of tumors with the accumulation of "cancerous" cells (malignant neoplasms). On the other hand, the so-called "benign tumor" is a simple localized mass of cells that multiply slowly and resemble their original tissue, rarely constituting a risk of death. ${ }^{1}$

Both the external or internal factors can promote the cancer, and in several cases, there is an association between them. External causes are related to the environment and habits or customs proper to a social and cultural environment, while internal causes are generally genetically predetermined, being linked to the body's ability to defend itself against external agents. These causal factors may interact in various ways, increasing the likelihood of malignant transformation in normal cells. ${ }^{1}$ 
Breast cancer is the second most common among women in Brazil and world, accounting for about $25 \%$ of new cases each year. It also affects men, but it is rarer ( $1 \%$ of all cases). The number of cases before 35 years is relatively small, growing progressively after 50 years. $^{2}$

The treatment for cancer may vary depending on the type, most commonly involving surgery for tumor removal, radiotherapy and chemotherapy, alone or in combination. The anticancer agents used in chemotherapy act systemically and possess anti-proliferative property, killing the cells in division. In general, they are classified as antimetabolic agents, alkylating agents, DNA complexing agents, inhibitors of mitosis and hormones, interfering with aspects of DNA replication, cell division, cell repair or translation. $^{3}$ The lack of selectivity of anticancer drugs results in significant toxicity to proliferating non-cancer cells. This toxicity, together with the resistance phenomena presented by tumors, are considered the main challenges in chemotherapy. ${ }^{4}$ Although extensive studies has been conducted in the last decades, prospects for the treatment of cancer patients still have a dismal scenario. Therefore, it is imperative to search for therapeutic alternatives with reduced toxicity and presenting better results. ${ }^{5}$

Natural products represent a significant source of inspiration for the design of biologically active molecules. Polyphenols containing the stilbene moiety are commonly founded in nature and have aroused, over the years, the interest of researchers due to their wide range of biological activities, usually associated with low toxicity. ${ }^{6}$ Among these compounds, the resveratrol, a compound abundant on grape and red wine, is particularly interesting due to its potent activity against various types of cancer, associated to a good safety profile. Several in vitro and in vivo assays attest the activity of resveratrol against various tumor cell lines, including lymphomas, melanomas, myelomas, breast, pancreas, colorectal, and hepatocell. ${ }^{7,8}$ However, some studies indicate that resveratrol has low oral bioavailability, being the investigation of analog molecules with better pharmacokinetic and pharmacodynamic profiles an interesting way. ${ }^{9}$

Recently, Murthy and co-workers (2016) ${ }^{6}$ presented the synthesis and antiproliferative activity against breast cancer cell lines (MDAMB-231) of 20 hybrid compounds, derived from resveratrol and 1,3,4-oxadiazole nucleus (Table 1). This nucleus has also attracted the attention of the Medicinal Chemists due to wide spectrum of biological activities such as anticancer, antibacterial, antifungal, antiviral. ${ }^{10}$ In this way, a continuity of this data set would be the realization of a Quantitative Structure-Activity Relationship (QSAR) study, to identify important molecular characteristics for the presented activity and the generation of a mathematical model to predict the activity of other analogues, designed to obtain more powerful optimized molecules.

The QSAR approach involves the use of several statistical techniques to relate the activity (pharmacological, toxic, environmental, etc.) presented by a series of chemical compounds with certain characteristics, known as molecular descriptors. These descriptors are numerical values that characterize different properties, either from the constitutional point of view (molar mass), geometric (autocorrelation of atomic properties), topological (polar surface area), quantum chemistry (electronic properties), among others. ${ }^{11,12}$ The final objective is to generate a mathematical model that includes molecular descriptors with high contribution in the activity presented by a series, allowing both the prediction of the activity of a molecule not yet synthesized and/or tested. In this way, it promotes an optimization of costs and time in the search for new drugs. ${ }^{12}$

Our research group has used strategies such molecular docking and QSAR studies for the Rational Planning of new bioactive compounds from natural, synthetic or semisynthetic origin. In this sense, this work presents an initial QSAR modeling for the resveratrol derivatives, considering their 
antiproliferative activities against breast cancer cell lines. We hope to identify the molecular descriptors related to the antiproliferative activity, generating a mathematical model to predict the activity of structurally related compounds.

\section{Material and Methods}

\subsection{Molecular structures and geometry optimizations}

Molecular structures of the 20 resveratroloxadiazole hybrids (Table 1 ) were constructed though $\mathrm{ACD} /$ ChemSketch $^{13}$ software and the inputs for geometry optimizations were edited on GaussView $6^{\otimes} .{ }^{14}$ Geometry optimizations were performed by PM6 semiempirical Hamiltonian, using the GAUSSIAN 09W ${ }^{\circledR}$ package $^{15}$ at CENAPAD-UFC (http://www.cenapad.ufc.br/) cluster environment.

Molecular descriptors were calculated using E-Dragon platform ${ }^{16}$, generating 1666 different variables. The $\mathrm{IC}_{50}$ for the cytotoxic activity on breast cancer cell lines was obtained from Murthy and coworkers ${ }^{6}$, being transformed to the $\log \left(I C_{50}\right)=\operatorname{plC} C_{50}$ (more active compounds assume higher values).

A variable selection procedure was performed using Ordered Predictors Selector (OPS) algorithm ${ }^{17}$ implemented in QSAR Modeling program ${ }^{18}$, reducing the number of variables from 1666 to 25 . After that, a systematic search was conducted using the BuildQSAR software ${ }^{19}$, considering four variables in a MLR (Multiple Linear Regression) modeling. At the end of this search, a model containing four variables was chose as the best, by the values of the coefficient of determination for calibration $\left(R^{2}\right)$ and coefficient of determination for leave-one-out cross validation $\left(Q^{2}\right)$. Considering the little size of data set (twenty compounds), training and test set were not defined, due to the risk of generating a very poor final model. We consider that, being the first data set of the class, the objective would be to generate a model that would allow an initial rationalization and prediction of new analogues. $^{20,21}$

The standard deviations of predicted values (s), Standard Deviation of Predictor Errors Sum of Squares (SPRESS) and correlation matrix between descriptors were also considered as validation procedures. Additionally, leave-n-out validations and $Y$ scrambling were performed. ${ }^{18}$ In the first models were sequentially constructed leaving one, two, until five variables ( $\mathrm{n}=01-25 \%$ of samples) at each time, in the similar manner to leave-one-out, varying the samples chosen at each step, totalizing ten calculations for each $n$ value. Then, the averages of ten values of $Q^{2}$ Ino were plotted to verify if these values were in the zone of $Q^{2}( \pm 0.1) .{ }^{11}$ For the $Y$ scrambling, 30 models were constructed with the values of $Y$ on the first column randomly mixed, of which the values of $R^{2}$ and $Q^{2}$ are expected to be low (the most less than 0.4 ), if there is no correlation by chance. ${ }^{11}$ 
Table 1. Resveratrol-oxadiazole hybrids studied in this paper ${ }^{6}$
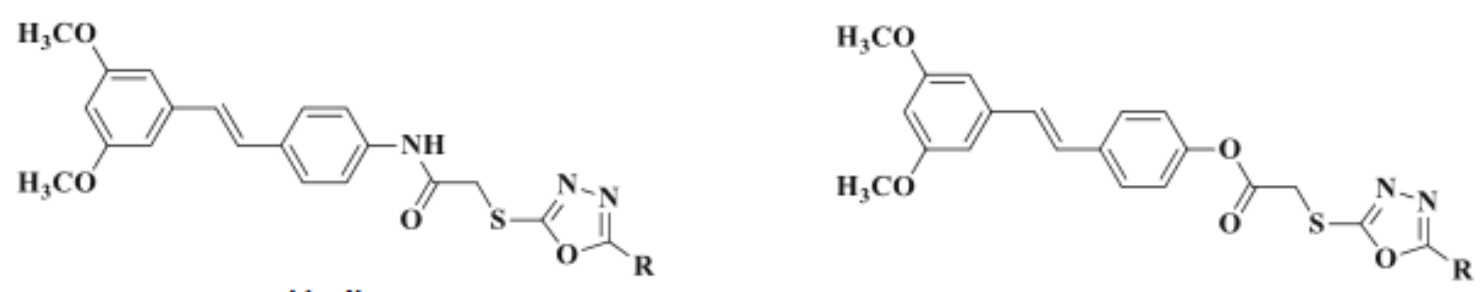

$1(\mathrm{a}-\mathrm{j})$

$2(a-j)$

\begin{tabular}{|c|c|c|}
\hline Compound & $\mathbf{R}$ & $\mathrm{Gl}_{50}(\mu \mathrm{M}) *$ \\
\hline $1 a$ & 3,4,5-Trimetoxifenil & 0.518 \\
\hline $1 b$ & Piridin-4-il & 0.47 \\
\hline 1c & 2-Fluorofenil & 0.510 \\
\hline $1 d$ & 2,6-Difluorofenil & 0.260 \\
\hline $1 e$ & 4-Fluorofenil & 0.221 \\
\hline $1 f$ & 4-(Trifluorometil)fenil & 3.484 \\
\hline $1 \mathrm{~g}$ & 3-(Trifluorometil)fenil & 0.094 \\
\hline $1 \mathrm{~h}$ & Pirazin-2-il & 0.590 \\
\hline $1 \mathbf{i}$ & 4-Metoxifenil & 0.490 \\
\hline $1 \mathbf{j}$ & $p$-Toluil & 3.516 \\
\hline $2 a$ & 3,4,5-Trimetoxifenil & 0.299 \\
\hline $2 b$ & Piridin-4-il & 0.692 \\
\hline $2 c$ & 2-Fluorofenil & 0.259 \\
\hline $2 d$ & 2,6-Difluorofenil & 1.000 \\
\hline $2 e$ & 4-Fluorofenil & 2.427 \\
\hline $2 f$ & 4-(Trifluorometil)fenil & 2.252 \\
\hline $2 g$ & 3-(Trifluorometil)fenil & 0.072 \\
\hline $2 \mathrm{~h}$ & Pirazin-2-il & 0.738 \\
\hline $2 \mathbf{i}$ & 4-Metoxifenil & 0.384 \\
\hline $2 \mathrm{j}$ & p-Toluil & 15.427 \\
\hline (Resveratrol) & - & 18.000 \\
\hline
\end{tabular}

*Molar concentration that inhibits $50 \%$ of net cellular growth for the breast cancer line

3. Results and Discussion
The Table 2 presents the values of the descriptors selected after OPS and systematic search algorithms. The best QSAR model generated can be visualized below (Equation 
1). The respective validation parameters, coefficient of determination for calibration $\left(R^{2}\right)$; coefficient of determination for leaveone-out cross validation $\left(\mathrm{Q}^{2}\right)$; correlation matrix between descriptors; standard deviation (s) and Standard Deviation of the Prediction Errors Sum of Squares (SPRESS) are presented on Table 3, attesting that was get a good QSAR model $\left(\mathrm{R}^{2}>0.7 ; \mathrm{Q}^{2}>0.6\right.$; correlations $<0.9$ and low values of $s$ and SPRESS). All the coefficients in equation presented statistical significance, at a confidence interval of $95 \%$, with $p<0.005$. Additionally, Leave-n-out cross validations and $Y$-scrambling procedures presented good values, as can be seen on Figures 1 and 2 .

Table 2. Values of $\mathrm{plC}_{50}$ and selected molecular descriptors

\begin{tabular}{cccccc}
\hline Compound & pIC $_{\mathbf{5 0}}$ & GATS8e & HATS8m & RDF030e & BEHP4 \\
\hline $\mathbf{1 a}$ & 6.28 & 1.098 & 0.032 & 16.066 & 3.513 \\
$\mathbf{1 b}$ & 6.32 & 1.36 & 0.067 & 8.433 & 3.48 \\
$\mathbf{1 c}$ & 6.29 & 1.157 & 0.063 & 7.934 & 3.505 \\
$\mathbf{1 d}$ & 6.58 & 1.057 & 0.074 & 8.399 & 3.503 \\
$\mathbf{1 e}$ & 6.65 & 1.103 & 0.053 & 7.8 & 3.503 \\
$\mathbf{1 f}$ & 5.45 & 1.06 & 0.092 & 10.022 & 3.517 \\
$\mathbf{1 g}$ & 7.02 & 0.888 & 0.05 & 11.704 & 3.515 \\
$\mathbf{1 h}$ & 6.22 & 1.224 & 0.069 & 10.902 & 3.459 \\
$\mathbf{1 i}$ & 6.3 & 1.2 & 0.062 & 7.3 & 3.507 \\
$\mathbf{1 j}$ & 5.45 & 1.354 & 0.043 & 9.189 & 3.519 \\
$\mathbf{2 a}$ & 6.64 & 1.227 & 0.033 & 11.326 & 3.51 \\
$\mathbf{2 b}$ & 6.15 & 1.509 & 0.07 & 4.119 & 3.474 \\
$\mathbf{2 c}$ & 6.58 & 1.295 & 0.069 & 5.017 & 3.5 \\
$\mathbf{2 d}$ & 6 & 1.183 & 0.087 & 6.995 & 3.5 \\
$\mathbf{2 e}$ & 5.61 & 1.247 & 0.078 & 4.772 & 3.5 \\
$\mathbf{2 f}$ & 5.64 & 1.157 & 0.082 & 8.287 & 3.513 \\
$\mathbf{2 g}$ & 7.14 & 1.007 & 0.064 & 7.415 & 3.51 \\
$\mathbf{2 h}$ & 6.13 & 1.341 & 0.09 & 4.515 & 3.453 \\
$\mathbf{2 i}$ & 6.41 & 1.343 & 0.059 & 4.584 & 3.503 \\
$\mathbf{2 j}$ & 4.81 & 1.499 & 0.059 & 6.411 & 3.515 \\
\hline & & & & & \\
\hline
\end{tabular}

$\mathrm{plC}_{50}=-4.0037( \pm 1.2438)$ GATS8e $-28.8228( \pm 11.6638)$ HATS8m $-0.1361( \pm 0.0737)$

RDF030e - $19.9727( \pm 9.1120)$ BEHP4 + $83.9180( \pm 32.9716)$ 
Table 3. Validation parameters of QSAR model

\begin{tabular}{c|cccc}
\hline \multicolumn{1}{c}{$\mathbf{R}^{2}$} & \multicolumn{2}{c}{$\mathbf{Q}^{2}$} & $\mathbf{S}$ & SPRESS \\
\hline 0.79 & \multicolumn{5}{c}{0.64} & \multicolumn{2}{c}{0.291} & 0.383 \\
\hline \multicolumn{5}{c}{ Correlation matrix } \\
\hline GATS8e & 1 & HATS8m & RDF030e & BEHP4 \\
HATS8m & 0.057 & 0.057 & 0.544 & 0.397 \\
RDF030e & 0.544 & 1 & 0.550 & 0.392 \\
BEHP4 & 0.397 & 0.550 & 1 & 0.328 \\
\hline
\end{tabular}

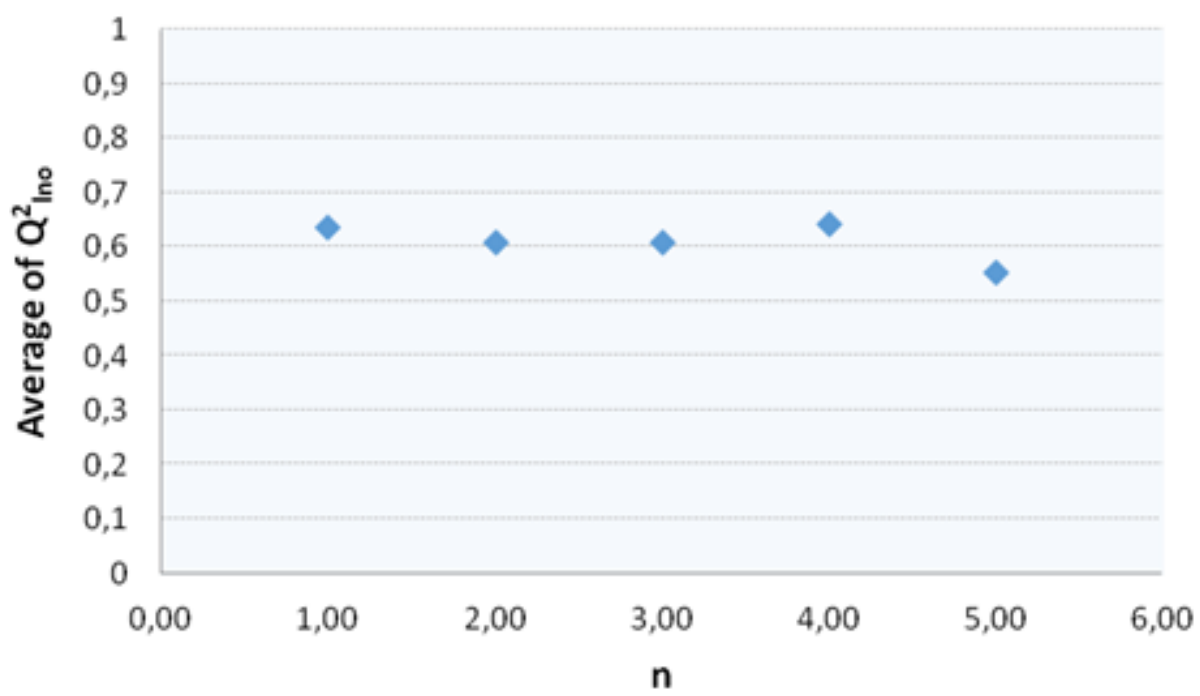

Figure 1. Averages of $\mathbf{Q}^{2}$ ino results for ten chosen variables for each $n$ values

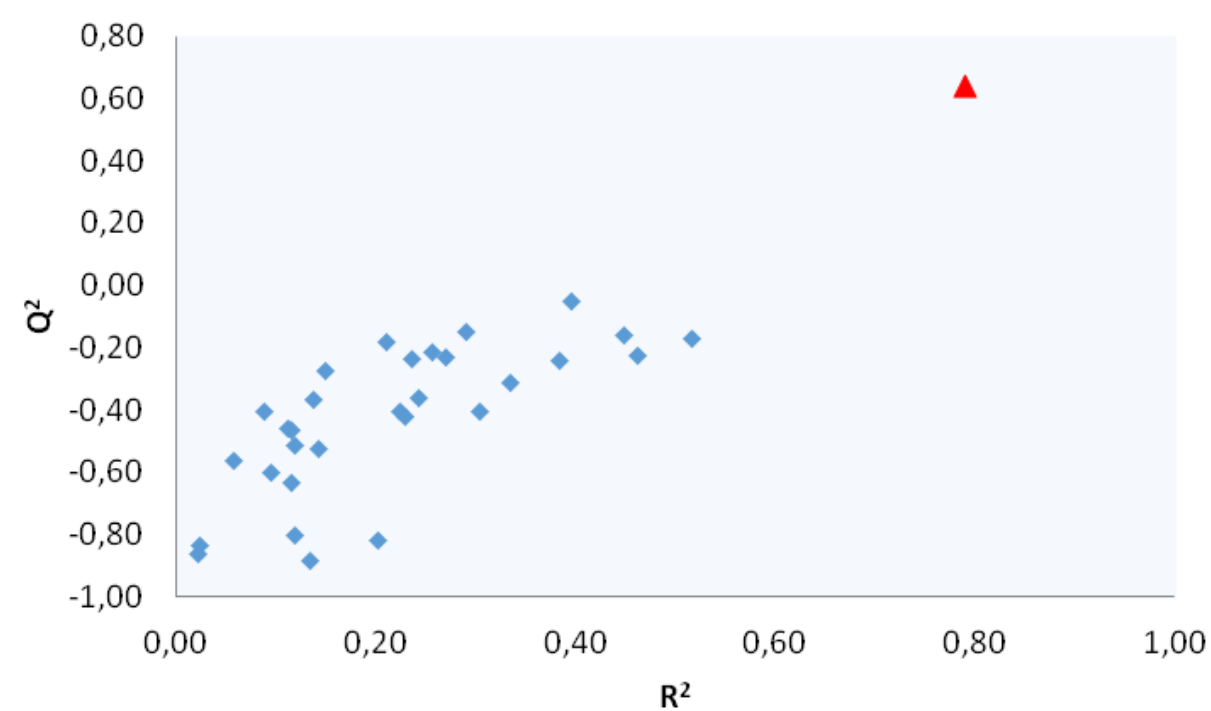

Figure 2. $Y$-scrambling results (in blue the values of $R^{2}$ and $Q^{2}$ for random models; in red the values for the original model) 
The Figure 3 presents the base plot for and observed (Y(obs)) values of plC $_{50}$ (Table 4), Pearson's correlation coefficient ( $r)$ which shows a good linearity of predictions, in calculation, considering calculated $(Y($ calc $))$ a QSAR perspective $(r=0.89)$.

Table 4. Experimental ( $\mathrm{Y}(\mathrm{obs}))$ and predicted $(\mathrm{Y}(\mathrm{calc}))$ values with residues

\begin{tabular}{lll}
\hline Y(obs) & $Y($ calc $)$ & Residue \\
\hline 6.280 & 6.248 & 0.032 \\
6.320 & 5.889 & 0.431 \\
6.290 & 6.386 & -0.096 \\
6.580 & 6.446 & 0.134 \\
6.650 & 6.948 & -0.298 \\
5.450 & 5.414 & 0.036 \\
7.020 & 7.124 & -0.104 \\
6.220 & 6.459 & -0.239 \\
6.300 & 6.289 & 0.011 \\
5.450 & 5.723 & -0.273 \\
6.640 & 6.408 & 0.232 \\
6.150 & 5.913 & 0.237 \\
6.580 & 6.157 & 0.423 \\
6.000 & 5.818 & 0.182 \\
5.610 & 6.123 & -0.513 \\
5.640 & 5.630 & 0.010 \\
7.140 & 6.928 & 0.212 \\
6.130 & 6.375 & -0.245 \\
6.410 & 6.252 & 0.158 \\
4.810 & 5.139 & -0.329 \\
\hline & & \\
\hline & & \\
\hline
\end{tabular}




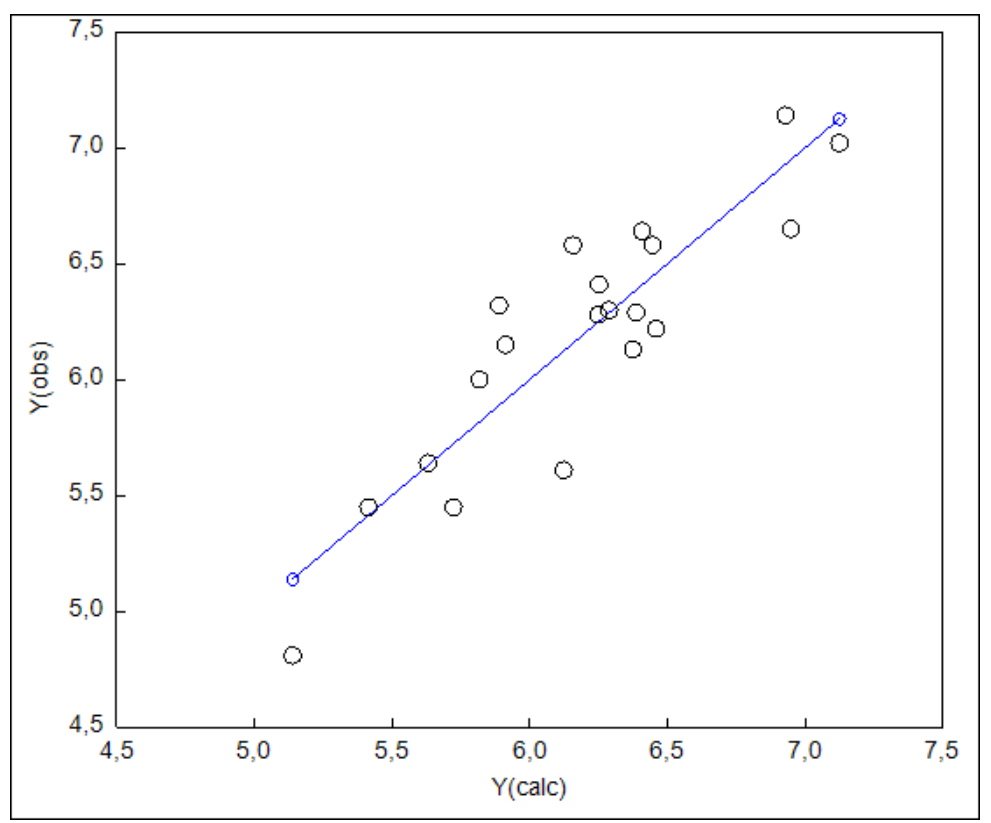

Figure 3. Correlation analysis between observed (experimental) and calculated values for $\mathbf{p l C}_{\mathbf{5 0}}$ $(r=0.89)$

Discussions about the chemical sense of the molecular descriptors are an important way to rationalize the structure-activity relationships, allowing the oriented design and optimization of new analogs. The first descriptor of the model, GATS8e, takes into account the correlations between atomic electronegativities, between atoms at a topological distance of 8 bonds. ${ }^{22}$

$$
\begin{gathered}
G A T S d w=\frac{\left(\frac{n-1}{2}\right)(A)}{B} \\
A=\left(\frac{1}{\Delta}\right)\left(\sum_{i=\mathbf{1}}^{n} \sum_{j=1}^{n} \llbracket \delta_{i j}\left(w_{i}-w_{j}\right)^{2}\right) \rrbracket \\
B=\sum_{i=1}^{n}\left(w_{i}-W\right)^{2}
\end{gathered}
$$

Where $w$ is the property under evaluation (electronegativity) and $W$ is their average value. The $\delta$ can takes 1 or 0 values, if the atomic distance is respectively equal to the specified value (8) or not. The greater differences in electronegativity between atoms separated by 8 bonds, higher the value of the descriptor. However, if the average of the electronegativity is high, the value tends to decrease. The regression coefficient shows that lower values of the descriptor tend to increase the activity. Compounds $\mathbf{1 g}$ and $\mathbf{2 g}$ have the tri-fluorine group and lower values of the descriptor. Compounds $\mathbf{1} \mathbf{j}$ and $\mathbf{2 e}$ have low activity values and higher values of this descriptor. Thus, electronegative atoms like 
fluorine replacing the ring increase the activity. But it is important to note that the position shows influence, and the tri-fluorine at para position decrease the activity (1f and 2f).
The HATS8m is a type of GETAWAY descriptor, derived from the molecular influence matrix ${ }^{22}$, which is calculated according to the equation below:

$$
\begin{gathered}
H=M \cdot\left(M^{T} \cdot M\right)^{-1} \cdot M^{T} \\
\text { HATSkw }=\sum_{i=1}^{n} \sum_{j=1}^{n}\left(w_{i} \boldsymbol{h}_{i i}\right) \cdot\left(w_{j} \boldsymbol{h}_{j j}\right) \delta\left(k ; d_{i j}\right)
\end{gathered}
$$

The atoms $i$ and $j$ separated by a $k$ distance ( 8 bonds) give the value of the descriptor, through its weighting scheme $w$ (in our case, mass $-m$ ) multiplied by the influence of the atom itself in the general molecular structure, denoted by the term $h$. Thus, presence of atoms at a distance of 8 bonds with greater mass increase the value of this descriptor. We observed that the compounds containing halogens, which are heavy, tend to higher value of this descriptor.

The regression coefficient in the model is negative, indicating that higher values tend to decrease activity. Compounds $\mathbf{1 f}$ and $\mathbf{2 f}$ have the highest values of this descriptor and we note that both have the tri-fluorine group on para position. Being three heavy atoms, the influence of this descriptor on the activity confirms the previous observation about the tri-fluorine on para position disadvantaging the activity.

The RDF030e is a descriptor calculated by Radial Distribution Function ${ }^{22}$, which express the probability of finding an atom in a sphere with a radius centered on the molecule, indicated by the particular index. In our case, "030" means $3 \AA$, weighted by the electronegativity. Then, the presence of the pairs of closer atoms with higher electronegativity promotes a higher value of this descriptor with the form is:

$$
R D F(R, w)=f \sum_{i=1}^{n-1} \sum_{j=1+1}^{n} w_{i} w_{j} e^{-\beta\left(R-r_{i j}\right)^{2}}
$$

Where $f$ is a scaling factor; $r_{i j}$ is the Euclidean distance between atoms $i$ and $j ; w_{i}$ and $w_{j}$ are the weights of the atoms $i$ and $j$ respectively; $n$ is the total number of atoms; $b$ is the smoothing parameter that defines the probability distribution of the individual interatomic distance. 6 can be interpreted as the temperature factor. $R$ is the considered radius.

The regression coefficient for this descriptor is negative, so, higher values correspond to lower activities. We can observe that the compounds containing the trimethoxyl groups on the ring have the highest values of the descriptor, due to the 3 nearby oxygen. If and $\mathbf{1 g}$ are important representatives of this descriptor. In general, in the two series containing amide or ester, higher values decrease the activity.

BEHP4 is a BCUT descriptor, which are the eigenvalues of a modified connectivity matrix, known as the Burden matrix. ${ }^{22}$ 
The Burden $M$ matrices are defined so that the diagonal elements $M_{w w}$ are the weights $w_{i}$ for the atom $A_{i}$, where the weights may be some property associated with the atoms, such as $m$ (relative atomic mass), $p$ (polarizability), and $e$ (Sanderson electronegativity) or $v$ (Van der Waals volume). The non-diagonal elements $M_{w k}$ are 1 if $\mathrm{k}=\mathrm{d}_{\mathrm{ij}}$ (atomic distance value indicated) and 0 otherwise.

The relative mass is defined as the ratio of the atomic mass of an atom to the carbon. Similarly, the other three weights $p, e$, and $v$ are scaled by the corresponding values for the Carbon.

For a given $w$ and $k$, there are two descriptors BCUT, BEHwk and BELwk: BEHwk is the highest positive maximum value of the matrix $M_{w k}$ and will be zero if there are no positive eigenvalues. In our case, the weight factor is the polarizability (P) by atomic distance of four bonds.

Structures $\mathbf{1 f}, \mathbf{1} \mathbf{j}, \mathbf{2} \mathbf{f}$ and $\mathbf{2} \mathbf{j}$ have higher descriptor values and smaller activities. The four are structures containing para substituent. $\mathbf{1} \mathbf{j}$ and $\mathbf{2} \mathbf{j}$ have higher values of the descriptor due to the methyl group, where the carbon has higher polarizability with respect to $\mathrm{O}, \mathrm{N}, \mathrm{F}$. The highest value of $\mathbf{1} \mathbf{f}$ and $\mathbf{2} \mathbf{f}$, even having 3 fluorine atoms that have low polarizability, can be justified by the carbon on $\mathrm{CF}_{3}$. In addition, pyridine compounds such as $\mathbf{1 b}$ and $\mathbf{2 b}$ have low relative values of this parameter, considering that nitrogen is less polarizable than carbon. This tendency is accompanied by molecules $\mathbf{1 h}$ and $\mathbf{2 h}$ which have a piperazine moiety.

Concluding this descriptive analysis, an additional observation that can be made is that the linker type (amide or ester) has no influence in potency of the compounds. In fact, the difference on activities can be attributed to substituent groups on terminal aromatic ring of the oxadiazole moiety, codified on descriptors analyzed above. Thus, the qualitative and quantitative discussions and models elucidated here can be used on the design and prediction of new analogs.

\section{Conclusion}

QSAR modeling is a good way to rationalize, in quantitative and qualitative forms, some aspects of the structure-activity relationships. Applications of the relatively simple molecular descriptors, as the provided by E-Dragon platform, together with search algorithms as OPS, have been able to providing relevant QSAR models with good interpretation of their physical-chemical sense.

In this study, we present an initial model to the design and prediction of the possible new analogs containing resveratrol-oxadiazole moieties revealing, in general, that compounds with high concentration of electronegative, heavy or polarizable groups on para position of the terminal aromatic ring of oxadiazole moiety tend to lowest activity, what cannot be said for other positions. Additionally, mathematical model generated can be used as an initial tool in the lead optimization process. Then, other analogs with various substituents at ortho or meta positions can be explored, in the search of more active compounds against breast cancer cell lines.

\section{Acknowledgments}

The authors thank the CNPq, CAPES, FACEPE and UNIVASF for the financial support and scholarships as well the CENAPAD-UFC for the computational facilities. The activity of access to the genetic patrimony was registered in SisGen with code \#AA1528C.

\section{References}

\footnotetext{
${ }^{1}$ Sítio do Instituto Nacional do Câncer (INCA). Disponível em:

<http://www1.inca.gov.br/conteudo_view.as p id=322>. Acesso em: 5 maio 2018.
} 
${ }^{2}$ Sítio do Instituto Nacional do Câncer (INCA). Disponível

em: <http://www2.inca.gov.br/wps/wcm/connect / tiposdecancer/site/home/mama>. Acesso em: 5 maio 2018.

${ }^{3}$ Horani, W.; Thawabteh, A.; Scrano, L.; Bufo, S. A.; Mecca, G.; Karaman R. Anticancer prodrugs - three decades of design. World Journal of Pharmacy and Pharmaceutical Sciences 2015, 4, 1751. [Link]

${ }^{4}$ Rautio, J.; Kumpulainen, H.; Heimbach, T.; Oliyai, R.; Oh, D.; Järvinen, T.; Savolainen, J. Prodrugs: design and clinical applications. Nature Reviews Drug Discovery 2008, 7, 255. [CrossRef]

${ }^{5}$ Singh, Y.; Murat, P.; Defrancq, E.; Recent developments in oligonucleotide conjugation. Chemical Society Reviews 2010, 39, 2054. [CrossRef]

${ }^{6}$ Murty, M. S. R.; Penthala, R.; Polepalli, S.; Jain, N.; Synthesis and biological evaluation of novel resveratrol-oxadiazole hybrid heterocycles as potential antiproliferative agents. Medicinal Chemistry Research 2016, 25, 627. [CrossRef]

7 Jazirehi, A. R.; Bonavida, B. Resveratrol modifies the expression of apoptotic regulatory proteins and sensitizes nonHodgkin's lymphoma and multiple myeloma cell lines to paclitaxel-induced apoptosis. Molecular Cancer Therapy 2004, 3, 71. [PubMed]

${ }^{8}$ Udenigwe C. C.; Ramprasath V. R.; Aluko R. E., Jones P. J. H.; Potential of resveratrol in anticancer and antiinflammatory therapy. Nutrition Review 2008, 66, 445. [CrossRef]

${ }^{9}$ Walle T.; Hsieh F.; Delegge M. H.; Oatis J. E.; Walle U. K.; High absorption but very low bioavailability of oral resveratrol in humans. Drug Metabolism and Disposition 2004, 32, 1377. [CrossRef]

${ }^{10}$ Oliveira C. S.; Lira B. F.; Filho J. M. B.; Lorenzo J. G. F.; Filho P. F. A. Synthetic approaches and pharmacological activity of 1,3,4-oxadiazoles: a review of the literature from 2000-2012. Molecules 2012, 17, 10192. [CrossRef]
${ }^{11}$ Alencar Filho, E. B.; Castro Silva, J. W.; Cavalcanti, S. C. H. Quantitative structuretoxicity relationships and molecular highlights about Aedes aegypti larvicidal activity of monoterpenes and related compounds. Medicinal Chemistry Research 2016, 25, 2171. [CrossRef]

${ }^{12}$ Cherkasov, A.; Muratov, E. N.; Fourches, D.; Varnek, A.; Baskin, II.; Cronin, M.; Dearden, J.; Gramatica, P.; Martin, Y. C.; Todeschini, R.; Consonni, V.; Kuz'min, V. E.; Cramer, R.; Benigni, R.; Yang, C.; Rathman, J.; Terfloth, L.; Gasteiger, J.; Richard, A.; Tropsha, A. QSAR Modeling: Where Have You Been? Where Are You Going To? Journal of Medicinal Chemistry 2014, 57, 4977. [CrossRef]

${ }^{13} \mathrm{ACD} /$ ChemSketch, version 12.01, Advanced Chemistry Development, Inc., Toronto, ON, Canada, www.acdlabs.com, 2015.

${ }^{14}$ GaussView, Version 6, Dennington, Roy; Keith, Todd A.; Millam, John M. Semichem Inc., Shawnee Mission, KS, 2016.

${ }^{15}$ Gaussian 09W, Revision B.01, Frisch, M. J.; Trucks, G. W.; Schlegel, H. B.; Scuseria, G. E.; Robb, M. A.; Cheeseman, J. R.; Scalmani, G.; Barone, V.; Petersson, G. A.; Nakatsuji, H.; Li, X.; Caricato, M.; Marenich, A. V.; Bloino, J.; Janesko, B. G.; Gomperts, R.; Mennucci, B.; Hratchian, H. P.; Ortiz, J. V.; Izmaylov, A. F.; Sonnenberg, J. L.; Williams-Young, D.; Ding, F.; Lipparini, F.; Egidi, F.; Goings, J.; Peng, B.; Petrone, A.; Henderson, T.; Ranasinghe, D.; Zakrzewski, V. G.; Gao, J.; Rega, N.; Zheng, G.; Liang, W.; Hada, M.; Ehara, M.; Toyota, K.; Fukuda, R.; Hasegawa, J.; Ishida, M.; Nakajima, T.; Honda, Y.; Kitao, O.; Nakai, H.; Vreven, T.; Throssell, K.; Montgomery, J. A., Jr.; Peralta, J. E.; Ogliaro, F.; Bearpark, M. J.; Heyd, J. J.; Brothers, E. N.; Kudin, K. N.; Staroverov, V. N.; Keith, T. A.; Kobayashi, R.; Normand, J.; Raghavachari, K.; Rendell, A. P.; Burant, J. C.; Iyengar, S. S.; Tomasi, J.; Cossi, M.; Millam, J. M.; Klene, M.; Adamo, C.; Cammi, R.; Ochterski, J. W.; Martin, R. L.; Morokuma, K.; Farkas, O.; Foresman, J. B.; Fox, D. J. Gaussian, Inc., Wallingford CT, 2016.

${ }^{16}$ Tetko, I. V.; Gasteiger, J.; Todeschini, R.; Mauri, A.; Livingstone, D.; Ertl, P.; Palyulin, V. 
A.; Radchenko, E. V.; Zefirov, N. S.; Makarenko, A. S.; Tanchuk, V. Y.; Prokopenko, V. V. Virtual computational chemistry laboratory--design and description. Journal of Computational Aided Molecular Design 2005, 19, 453. [CrossRef]

${ }^{17}$ Teófilo, R. F.; Martins, J. P.; Ferreira, M. M.

C. Sorting variables by using informative vectors as a strategy for feature selection in multivariate regression. Journal of Chemometrics 2009, 23, 32. [CrossRef]

${ }^{18}$ Martins. J. A. M.; Ferreira, M. M. C. QSAR modeling: um novo pacote computacional open source para gerar e validar modelos QSAR. Química Nova 2013, 36, 554. [CrossRef]

${ }^{19}$ De Oliveira, D.B.; Gaudio, A. C.; BuildQSAR: A New Computer Program for QSAR Analysis. Quantitative Structure-Activity Relationships 2001, 19, 599. [CrossRef]
20 Silva, J. B. P., Ramos, M. N., Neto, B. B., Melo, S., Falcão, E. P. S., Catanho, M. T. J. A. Quantitative Structure-Activity Relationships (QSAR) of 4-Amino-2,6-diarylpyrimidine-5carbonitriles with Antiinflammatory Activity. Journal of the Brazilian Chemical Society 2008, 19, 337. [CrossRef]

${ }^{21}$ Alencar Filho, E. B; Castro Silva, J. W. A Quantitative Structure-Activity Relationships (QSAR) Study of Piperine Based Derivatives with Leishmanicidal Activity. Orbital: The Electronic Journal of Chemistry 2017, 9, 43. [CrossRef]

${ }^{22}$ Sítio da Talete products. Disponível em: <http://www.talete.mi.it/products/dragon molecular_descriptor_list.pdf $>$. Acesso em: 20 abril 2018. 